\title{
THE EFFECTS OF COSMOPOLITANISM AND TRADITION ON THE EVALUATION AND INTENTIONS OF THE USERS OF FAST FOOD RESTAURANTS
}

\author{
Srdjan Sapic* \\ Faculty of Economics, University of Kragujevac, Kragujevac, The Republic of Serbia
}

In terms of modern life, consumers have an increasing number of options when it comes to choosing a restaurant when they do not wish to eat at their homes. Fast food restaurants represent one of those options. In addition to domestic fast food restaurants, the development of global restaurant chains is also noticeable. The purpose of this paper is to identify the factors that affect the evaluations of products and services and the intentions of users in terms of using the services of fast food restaurants. In relation to that, it is important to analyze the factor of cosmopolitanism and tradition. Cosmopolitanism, as the willingness of people to cooperate with other cultures and tradition, and tradition, as a reflection of respect for the customs and ideas that are imposed on individuals by their culture or religion, affect consumers' intentions and their willingness to use the services of foreign fast food restaurants. In accordance with that, the purpose of this research study is to determine if and how cosmopolitanism and tradition affect the evaluations of products and services and consumers' intention concerning foreign restaurant chains and domestic fast food restaurants of both the local and the family types. The results of the conducted empirical research show that cosmopolitanism positively affects the evaluations of the products and services of foreign restaurants and that tradition positively affects the evaluations of the products and services of domestic fast food restaurants.

Keywords: cosmopolitanism, tradition, evaluations of products and services, consumer behavioral intentions, fast food restaurants

\section{JEL Classification: M31, L83}

\section{INTRODUCTION}

In the last decades, there has been a considerable growth in the restaurant industry at a global level.

* Correspondence to: S. Sapic, Faculty of Economics, University of Kragujevac, Dj. Pucara 3, 34000 Kragujevac, The Republic of Serbia; e-mail: ssapic@kg.ac.rs
Accordingly, the choice that consumers have when they wish to "eat out" is constantly increasing and competition among restaurants of different types is growing. This concept of restaurants was created in the United States of America at the beginning of the 1950s and today it has grown into a global industry, with annual incomes worth over $\$ 580$ billion, more 
than 13 million employees and an annual growth rate of $2.8 \%$ (IBISWorld). Fast food restaurants are mostly a part of global fast food restaurant chains or franchises and their products are mostly a part of a standardized production program, with certain local variations. Some of the most famous global fast food restaurant chains are McDonald's, Subway, KFC, Pizza Hut, Burger King and others. Most of these restaurants have been present in the markets of a large part of Europe for several decades, as well as in the Serbian markets, but for a shorter period of time. Specifically, the first McDonald's restaurant in Belgrade was opened in 1988. Aside from these global fast food restaurant chains, a great number of domestic fast food restaurants have been present in the Serbian market. These restaurants are mostly of the local and the family types (bakeries, barbecue restaurants, pizzerias, and so on), they are not a part of franchises and they offer their consumers different kinds of products, specific in certain areas and suited to local tastes.

In the conditions of harsh competition and a struggle to attract consumers, it is very important for the management of restaurants to understand the factors that influence consumers' behavior and intentions concerning their using the services of domestic and foreign fast food restaurants. In the literature on marketing, researchers have discovered and analyzed the numerous factors that affect consumers' behavior and their decisions regarding the purchase of different kinds of domestic and foreign products (Verlegh, 2007; Sharma, 2011; Zeugner-Roth, Žabkar \& Diamantopoulos, 2015). However, there is a lack of such studies of the topic of the service sector and there are virtually no studies of this topic, especially when fast food restaurants are concerned. For the purpose of overcoming the noticed research gap, this paper has analyzed the impact of the two factors cosmopolitanism and the consumer's tradition - on the evaluations of products and services and the consumer's behavioral intentions with respect to domestic and foreign fast food products.

The subject of this research study is the analysis of the behavior demonstrated by the users of fast food restaurant services, as well as the analysis of the effects of the country of origin of restaurants themselves.
Namely, the basic assumption the research study rests on is that the country of origin of fast food restaurants affects the consumer's evaluations and intentions. In accordance with that, the subject of this research is the analysis of the way in which cosmopolitanism and tradition affect the formation of consumers' evaluations and their intentions when using the services of foreign fast food restaurants (which offer a standardized production program with certain local variations) and domestic fast food restaurants (which offer different kinds of products, specific in certain areas and suited to local tastes) are concerned.

The basic aim of the research is to use a conceptual model and predict the impact of cosmopolitanism and tradition on the evaluations of services and products in fast food restaurants and the consumer's intentions of using the services provided by these restaurants.

The research study was conducted in the territory of Kragujevac and the surrounding cities. The analysis of the aforementioned connections was carried out using the questionnaire method. Within the research, descriptive statistics, the exploratory factor analysis and the reliability analysis were used, all of which confirmed the existence of the two factors and their internal consistency. The testing of the hypotheses concerning the impact of the factors on the evaluations and intentions of the users of fast food restaurant services was carried out using the multiple and the simple regression analyses. The examination of the statistically significant differences among the groups of the respondents in the sample was performed using the one-way analysis of the variance and the independent-samples t-test.

The paper is structured into five parts. After the introductory considerations, the theoretical conceptualization of the observed factors (cosmopolitanism and tradition) that affect consumers' evaluations and their intentions is introduced. The idea of the effect of the country of origin was also analyzed, as well as the impact of this effect on the evaluations and intentions formed by the consumer in relation to buying the products and using the services of domestic and international companies. In this part, the basic hypotheses of the research study are also defined, based on the introduced theoretical 
considerations and the results of the previous studies. In the next part, the conceptual model of the research, including the research methods and the analyses used in the paper, is primarily explained. The main results of the empirical research, based on which the introduced hypotheses were tested, are presented in the fourth part. The last part of the paper includes the analysis of the results of the research, the concluding considerations and a connection to the results of the previous studies. At the very end of the paper, the basic limitations of the research, as well as the potential future directions in the research of the described problem, are pointed out.

\section{A LITERATURE REVIEW AND HYPOTHESES DEFINING}

\section{Consumer Cosmopolitanism}

Apart from the noticeable processes of international trade, the current processes of global integration also include political cooperation and international travel, and the development of the socio-psychological perception of the world as a unique place as well (Westjohn, Arnold, Magnusson \& Reynolds, 2016). One consequence of this is that people have increasingly been forming their attitudes bearing in mind the global availability of multinational products and brands, which leads to the creation of a homogeneous global consumer culture (Alden, Steenkamp \& Batra, 1999; Cleveland \& Laroche, 2007). Consumer cosmopolitanism is one of the dimensions of the consumer's behavior arising from an adjustment to the global consumer culture (Cleveland \& Laroche, 2007).

Even though the term "cosmopolitanism" has often been associated with every person who moves a lot in global circles, it is more encompassing if the notion is considered as a specific set of certain people's beliefs, attitudes and qualities, including their willingness to cooperate with other cultures, as well as the level of competences towards them (Cleveland \& Laroche, 2007). A more general conceptualization of the term was given by P. Riefler, A. Diamantopoulos and J.
A. Siguaw $(2012,287)$, according to whom consumer cosmopolitanism can be considered as the degree to which the consumer:

- shows open-mindedness towards other countries and cultures,

- appreciates the variety being a consequence of the availability of products of a different national and cultural origin and

- has a positive tendency towards consuming products from different countries.

Therefore, consumers with a developed sense of cosmopolitanism have an open-minded awareness of the world and its cultural differences (Skrbis, Kendall \& Woodward, 2004), they have positive attitudes towards the availability of products from different countries and constantly enjoy the products, places and experiences that originate from foreign cultures (Riefler \& Diamantopoulos, 2009).

Consumer cosmopolitanism is the subject of many studies, in which it is often considered as a variable through which the consumer's intention of purchasing certain local and global products can be predicted (Cleveland, Laroche \& Papadopoulos, 2009; Riefler \& Diamantopoulos, 2009; Zeugner-Roth, Žabkar \& Diamantopoulos, 2015). That is how K. P. Zeugner-Roth, V. Žabkar and A. Diamantopoulos (2015) proved that cosmopolitanism positively affects the purchase of foreign products, as well as the consumer's intentions and willingness to buy this kind of products. A similar study has proved that a strong sense of the national identity greatly affects the consummation of local products in the food sector, whereas cosmopolitanism greatly affects the consummation of global products (Cleveland, Papadopoulos \& Laroche 2011). However, there is a small number of studies focused on the analysis of cosmopolitanism in the service sector and its impact on the consumer's behavior (Nijssen \& Douglas, 2008; Wang \& Mattila, 2015). Based on the theoretical concepts and the aforementioned studies, it can be assumed that consumers with a strong sense of cosmopolitanism prefer using the services of foreign fast food restaurants, taking into consideration the 
fact that they are mostly a part of the globally present fast food chains. On the other hand, such consumers will likely form the negative perceptions of the products and services of local, i.e. domestic fast food restaurants. In accordance with that, it is possible to formulate the following hypotheses:

H1a: Cosmopolitanism has a statistically significant and negative impact on the evaluation of the products and services of domestic fast food restaurants.

H1b: Cosmopolitanism has a statistically significant and positive impact on the evaluation of the products and services of foreign fast food restaurants.

\section{Tradition}

The notion of tradition refers to respect for, acceptance of and dedication to the customs and ideas imposed on individuals by their culture or religion (Schwartz, 1992; 1994). Additionally, traditional values imply modesty, humility and moderation in life, as well as a dedication to the values and the way of life accepted in society. As a personal trait, tradition characterizes the individuals who approve of a conservative way of rearing children, who have traditional values and religious beliefs, who respect their elders, as well as conventionally proper traits and behavior (Grünhagen, Dant \& Zhu, 2012). According to the classification suggested by S. H. Schwartz (1992), tradition represents one of the ten basic personal values that can be classified into the four groups of higher-rank values. The group of the higher-rank values which tradition belongs to refers to preservation, which implies self-restraint, order and avoiding changes. These values are aimed at maintaining and preserving cultural, familial and religious traditions (Schwartz, 2012). Beside tradition, the values of preservation also include the consumer's conformity, security and opposition to changes, which may mean that the consumers who consider tradition to be significant prefer domestic restaurants to foreign ones, which represent a novelty in the market and a change in relation to the existing, traditional Serbian fast food restaurants.
The research study conducted by J.-B. E. M. Steenkamp and M. G. de Jong (2010) showed that assigning significance to tradition, as an individual's general value, negatively affects the consumer's attitudes towards global products, whereas it positively affects consumers' attitudes towards local products. Additionally, J.-B. E. M. Steenkamp, F. T. Hofstede and M. Wedel (1999) proved that the values of preservation, including tradition, negatively affect consumers' innovativeness concerning the acceptance of new, foreign products in the market. Other authors also obtained similar results. Cleveland et al, (2013) determined that tradition negatively affects the consumer's attitudes towards globalization and the acceptance of global consumer culture. Aside from these general studies, the studies dealing with researching into the impact of tradition on the consumer's behavior in the service sector are very rare. Based on the theoretical conceptualization of the notion of tradition and the results of empirical research, traditional values can be assumed to positively affect the consumer's perceptions of domestic fast food restaurants, whereas they negatively affect the consumer's perceptions of the products and services of foreign fast food restaurants. In accordance with that, it is possible to formulate the following hypotheses:

H2a: Tradition has a statistically significant and positive impact on the evaluation of the products and services of domestic fast food restaurants.

$\mathrm{H} 2 \mathrm{~b}$ : Tradition has a statistically significant and negative impact on the evaluation of the products and services of foreign fast food restaurants.

\section{The Effects of the Country of Origin - the Evaluation of Products and Behavioral Intentions}

The effects of the country of origin of products have been the subject of research in the scientific literature for several decades. The said effects imply that some consumers show positive or negative predispositions 
towards the purchase of different products, depending on the country of origin which they are associated with (Verlegh \& Steenkamp, 1999; Josiassen \& Harzing, 2008; Magnusson, Westjohn \& Zdravkovic, 2011). By analyzing the relevant literature, it can be concluded that the country of origin of products and services affects the evaluation of products and the consumer's behavior with respect to the purchase (Peterson \& Jolibert, 1995; Verlegh \& Steenkamp, 1999; Pharr, 2005; Sharma, 2011). Within this research, as the effects of the impact of the country of origin of fast food restaurants, we considered the evaluation of products and services, as well as their impact on the consumer's behavioral intentions, in terms of using the services of domestic and foreign fast food restaurants.

The country of origin serves as a very important basis for the evaluations consumers form with respect to products and services (Hong \& Wyer, 1989). A lot of authors consider that the country of origin of products and/or services and its image either positively or negatively affect the evaluations of the products that originate from those countries and this issue has been the subject of research conducted in numerous studies (Laroche, Papadopoulos, Heslop \& Mourali, 2005; Costa, Carneiro \& Goldszmidt, 2016). According to M. Laroche et al, (2005), the evaluation of products refers to the sum of the attitudes that a consumer has towards a product, which is manifested through the sense of liking the product, the pleasure arising from one's owning the product, as well as a desire to purchase it. Consumers tend to analyze certain signs while they are forming their respective evaluation of products and services. These signs may be internal, the tangible characteristics of the product (its design, shape, color), as well as external, not so tangible characteristics of the product (its price, warranty and brand, and the county of origin of the product) (Manrai et al, 1998; Verlegh \& Steenkamp, 1999). It should be pointed out that the latter group of signs gains in significance when consumers cannot completely objectively evaluate a product. Bearing in mind the level of the intangible elements present in the case of services, it can be concluded that they are particularly important for the evaluations formed by the users of services.
For the purpose of analyzing the effects of cosmopolitanism and tradition on consumers' evaluations and intentions, this research relies on the Social Identity Theory (Tajfel, 1978; Tajfel \& Turner, 1986), according to which individuals form their attitudes and behavior in accordance with their sense of belonging to a particular group. Based on this theory, the said factors may have a positive or a negative impact on consumers' attitudes and their behavior towards the "in" group, i.e. their country, as well as towards the "out" group, i.e. foreign countries. In this research, the nature of the impact of the two said factors on consumers' attitudes and behavior towards domestic and foreign fast food restaurants is analyzed. In this manner, the model that encompasses the factors significant for understanding the way in which consumers make decisions on using the services of either foreign or domestic fast food restaurants is observed.

Behavioral intentions can be observed as a distinctive type of belief, where the object is the person him- or herself and the attribute is always behavior (Fishbein \& Ajzen, 1975, 12). Similarly, R. L. Oliver (1996) defined behavioral intentions as a high likelihood or probability that a person will engage him- or herself in a given behavior. Concisely, they can be described as a plan to perform a certain type of behavior. Apart from that, there is a connection between intentions and a real behavior, which implies that the stronger the intentions are to assume a certain type of behavior, the stronger the probability is that that behavior will be turned into an action. (Kim, Ham, Yang \& Choi, 2013).

During the development of the research study and the conceptual model, some of the basic elements of the Theory of Reasoned Action (Ajzen \& Fishbein, 1980) were used, which indicates that behavioral attitudes and subjective norms influence an intention, which then influences consumers' behavior; and also the Theory of Planned Behavior (Ajzen, 1991), according to which consumers' attitudes and evaluations affect their intentions in behavior and ultimately affect the consumer's actual behavior. A similar conceptual framework was used in a number of previous and relevant research studies (Riefler \& Diamantopoulos, 
2009; Zeugner-Roth et al, 2015). In the case of this research study, intentions in behavior are analyzed through three segments, and these are: intentions for trying out, using services and spreading positive information about fast food restaurants (McCall \& Lynn, 2008; Sharma, 2011). In accordance with the above-mentioned theoretical concepts, it is possible to define the following hypotheses that describe the relationship between consumers' evaluations and their:

H3a: The evaluations of products and services in domestic fast food restaurants have a positive and statistically significant impact on consumers' intentions regarding the use of the services of these restaurants.

$\mathrm{H} 3 \mathrm{~b}$ : The evaluations of products and services in foreign fast food restaurants have a positive and statistically significant effect on consumers' intentions regarding the use of the services of these restaurants.

\section{RESEARCH MODEL}

Based on the literature overview and the hypotheses set, a conceptual model of research can be created, by which the relations among the given variables are represented. Within the model, research is done in the positive impact of cosmopolitanism and tradition on the evaluations of the products and services of domestic and foreign fast food restaurants. Apart from that, the impact of consumers' evaluations on consumers' behavioral intentions regarding their using the services of the aforementioned fast food restaurants is also researched in. These relations are presented in Figure 1.

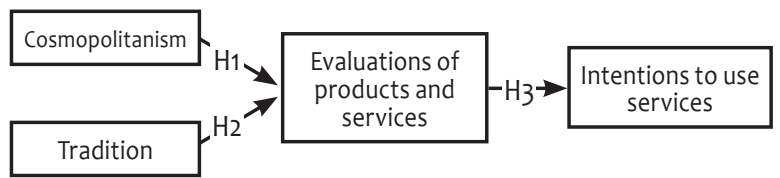

Figure 1 The conceptual model of the research

\section{Methodology}

In order to confirm the existence of the previously mentioned relations, we conducted the research in the territory of the city of Kragujevac and the neighboring cities by using the survey method. The research resulted in the 364 surveys that were collected on the simple random sample. The interviewing had been done in the period from March to June 2017. The data were obtained by the distribution of the questionnaire in the paper form, where the respondents evaluated the level of their agreement with the given statements on the seven-degree Likert scale (where 1 stands for I strongly disagree, 7 - I strongly agree). The structure of the sample according to the socio-demographic characteristics is presented in Table 1.

Table 1 The descriptive statistics for the respondents' characteristics

\begin{tabular}{llc}
\hline \multirow{2}{*}{ Gender } & Male & $\begin{array}{c}\text { \% of } \\
\text { Respondents }\end{array}$ \\
\hline \multirow{4}{*}{ Age } & Female & 45.6 \\
& Younger than 18 & 54.4 \\
\hline & $19-24$ & 4.4 \\
& $25-29$ & 30.4 \\
& $30-39$ & 14.8 \\
& $40-49$ & 14.6 \\
& $50-59$ & 15.4 \\
& 60 and over 60 & 10.7 \\
& Elementary school & 9.7 \\
\hline \multirow{4}{*}{ Education } & High school & 2.2 \\
& Undergraduate & 36.5 \\
& Studies & 19.3 \\
& Vocational studies & 13.2 \\
& Graduate studies & 22.3 \\
& Post-graduate studies & 5.1 \\
& PhD studies & 1.4 \\
\hline
\end{tabular}

Source: Author 
As was previously stated, we used four variables in the research and the respondents' statements were formulated in accordance with the overview of the relevant literature. Cosmopolitanism was measured by using the five statements taken from the study whose authors are Z. Jin, R. Lynch, S. Attia, B. Chansarkar, T. Gülsoy, P. Lapoule and M. Ungerer (2015). The statements related to tradition had been taken from the study whose authors are S. Schwartz et al, (2012). As for the effects of the country of origin, product evaluations and behavioral intentions, i.e. the statements related to these variables - they had been taken from a study conducted by P. Sharma (2011).

The statistical analysis and the data analysis were performed by using the SPSS (Statistical Package for Social Sciences, Version 21.0) software package. Before analyzing the influence of certain variables on consumers' evaluation and intentions, we had also performed the grouping of the conclusions within the two factors - cosmopolitanism and consumers' tradition - by applying the exploratory factor analysis (the method of the main components, the varimax rotation). After this analysis, we also examined the effect of the obtained factors on the evaluation of the products and services in the case of domestic and foreign fast food restaurants by applying the multiple regression analysis, as well as the impact of consumers' evaluations on their intentions of using domestic and foreign fast food restaurants through a free linear regression. A simple regression analysis was used to test Hypotheses $\mathrm{H} 3 \mathrm{a}$ and $\mathrm{H} 3 \mathrm{~b}$. In the end, we examined the statistical significance of the differences between the mean values of the individual groups of the samples by using the singlefactor analysis of the variance and the t-test of the independent samples.

\section{RESEARCH RESULTS}

For the purpose of grouping the findings from the questionnaire into the factors, an exploratory factor analysis was performed. This conducted analysis led us to the two factors: cosmopolitanism and consumers' tradition. The indicators that have to be taken into consideration when assessing the justification of the application of the exploratory factor analysis are Bartlett's Sphericity Test and Kaiser-Meyer Olkin's (KMO) Indicator of the Adequacy of the Sample. The $\mathrm{KMO}$ indicator value for this study is 0.802 , whereas Bartlett's Sphericity Test has a statistically significant value (Sig. $=0.000)$, which indicates that the use of the factor analysis is justified.

By analyzing the value of the Kronbach Alpha Coefficient (Cronbach's $\alpha$ ), it can be noticed that both factors have an appropriate level of internal consistency, which is higher than the recommended value of 0.7 (Nunnally, 1978). The values of factor loading in each factor, as well as the Kronbach Alpha Coefficient values for both factors, are shown in Table 2.

The results of the descriptive statistics accounted for in Table 2 are indicative of the fact that the respondents rated the group of the statements related to tradition better than the statements related to cosmopolitanism. The statement about the importance of family values and religious customs (AS $=5.90)$ has the highest mean value, whereas the statement focused on the exchange of ideas with people from other countries and cultures (AS $=4.93$ ) is characterized by the lowest mean value.

In order to examine the mutual impact of the obtained factors on customers' evaluations, a multiple linear regression was used in the case of domestic and foreign fast food restaurants. The results of this analysis are presented in Table 3. When the impact of cosmopolitanism on the evaluation of the products and services of domestic fast food restaurants is concerned, it can be noticed that it has no statistically significant impact on consumers' evaluations $(\beta=0.004$, Sig. $=0.939)$. This result implies that the H1a hypothesis is refuted. On the other hand, cosmopolitanism has a positive and statistically significant impact on consumers' evaluations of foreign fast food restaurants $(\beta=0.373$, Sig. $=0.000)$, so Hypothesis H1b is confirmed. 
Table 2 The results of the exploratory factor analysis

\begin{tabular}{|c|c|c|c|c|}
\hline Statements & $\begin{array}{l}\text { Factor } \\
\text { loading }\end{array}$ & $\begin{array}{c}\text { Cronbach's } \\
a\end{array}$ & AS & SD \\
\hline Cosmopolitanism & & 0.887 & & \\
\hline I enjoy exchanging ideas with people from other countries and cultures. & 0.798 & & 4.93 & 1.617 \\
\hline I am interested in learning about people from other countries. & 0.884 & & 5.24 & 1.538 \\
\hline $\begin{array}{l}\text { I like spending time with people from other countries in order to learn } \\
\text { about their views and approaches to life. }\end{array}$ & 0.897 & & 5.04 & 1.503 \\
\hline $\begin{array}{l}\text { I love observing people from other countries so I can learn something } \\
\text { from them. }\end{array}$ & 0.851 & & 5.15 & 1.398 \\
\hline I like learning how others approach the challenges of life. & 0.711 & & 5.20 & 1.408 \\
\hline Tradition & & 0.866 & & \\
\hline It is important for me to maintain traditional values and beliefs. & 0.852 & & 5.46 & 1.430 \\
\hline Family values and religious customs are important to me. & 0.899 & & 5.90 & 1.334 \\
\hline I highly appreciate traditional values in my culture. & 0.907 & & 5.76 & 1.351 \\
\hline Bartlett's Spherical Test & & Sig. $=0.000$ & & \\
\hline KMO & & 0.802 & & \\
\hline
\end{tabular}

Source: Author

Table 3 The results of the multiple linear regression (the dependent variable - The consumers' evaluation of domestic and foreign fast food restaurants)

\begin{tabular}{lcccccc}
\hline & \multicolumn{4}{c}{ Consumers' evaluation } \\
\cline { 2 - 7 } & \multicolumn{2}{c}{$\begin{array}{c}\text { Domestic fast food } \\
\text { restaurants }\end{array}$} & \multicolumn{3}{c}{$\begin{array}{c}\text { Foreign fast food } \\
\text { restaurants }\end{array}$} \\
\hline Variable & $\beta$ & Sig. & VIF & $\beta$ & Sig. & VIF \\
\hline $\begin{array}{l}\text { Cosmo- } \\
\text { politanism }\end{array}$ & 0.004 & 0.939 & 1.020 & 0.373 & 0.000 & 1.018 \\
\hline Tradition & 0.321 & 0.000 & 1.020 & -0.130 & 0.807 & 1.018 \\
\hline
\end{tabular}

Source: Author

When the influence of tradition on consumers' evaluations of the products and services of domestic fast food restaurants is concerned, the results indicate that there is a positive and statistically significant influence on the evaluations of the products and services of domestic restaurants $(\beta=0.321$, Sig. = 0.000 ), which is indicative of the fact that Hypothesis $\mathrm{H} 2 \mathrm{a}$ is confirmed. Apart from that, tradition has a negative impact on consumers' evaluations of foreign restaurants, but its impact is not statistically significant $(\beta=-0.130$, Sig. $=0.807)$, so Hypothesis $\mathrm{H} 2 \mathrm{~b}$ is refuted. In addition to the results presented above, it can be noticed that multicollinearity is not a problem in the relations that were the subject of our observation, since the value of the variance factor (VIF) in all the cases is below the recommended value of 5 (Field, 2000). It can be noticed that cosmopolitanism has a more pronounced impact on the evaluations of the products and services of foreign restaurants in relation to the influence that tradition has on the evaluations that consumers make in relation to the products and services of domestic fast food restaurants.

In accordance with the other set hypotheses, the impact that consumers' evaluations have on their intentions in terms of their future behavior was also the subject matter of our study. The results of this analysis are given in Table 4 . When the impact of the evaluations of the products and services on consumers' intentions, in terms of using the services of domestic fast food restaurants, are observed, it can be noticed that there is a pronounced, positive and statistically significant impact $(\beta=0.566$, Sig. $=0.000)$, so Hypothesis H3a has been confirmed. 
Table 4 The results of the linear regression (the dependent variable - The consumers' intentions of using the services of domestic and fast food restaurants)

\begin{tabular}{lccccccc}
\hline & \multicolumn{2}{c}{$\begin{array}{c}\text { Domestic fast food } \\
\text { restaurants }\end{array}$} & \multicolumn{3}{c}{$\begin{array}{c}\text { Foreign fast food } \\
\text { restaurants }\end{array}$} \\
\hline Variable & $\begin{array}{c}\mathrm{R} \\
\text { Square }\end{array}$ & $\beta$ & Sig. & $\begin{array}{c}\mathrm{R} \\
\text { Square }\end{array}$ & $\beta$ & Sig. \\
\hline $\begin{array}{l}\text { Consumers' } \\
\text { evaluations }\end{array}$ & 0.366 & 0.566 & 0.000 & 0.432 & 0.657 & 0.000 \\
\hline
\end{tabular}

Source: Author

When the impact of consumers' evaluations on the use of foreign fast food restaurants is in question, we determined a very high, positive and statistically significant impact $(\beta=0.657$, Sig. $=0.000)$, which implies that the $\mathrm{H} 3 \mathrm{~b}$ hypothesis is also confirmed. Regarding the relationship between consumers' evaluations and their intentions, it can be noted that the strength of the impact of the evaluations of products and services measured by the $\beta$ coefficient is more pronounced in the case of foreign restaurants than the domestic ones.

Apart from the relations that were the subject matter of our analysis, we also examined whether there were statistically significant differences among the mean values of the groups within the sample. Firstly, whether there were statistically significant differences among the mean values within the groups of the sample was analyzed. We started by analyzing if there were statistically significant differences in terms of attitudes about cosmopolitanism and tradition among the different groups of the respondents, by applying the criterion of age and education, which we did using the single-factor analysis of the variance (ANOVA). The results of this analysis, accounted for in Table 5, indicate that there are statistically significant differences among the group of the respondents in terms of cosmopolitanism, according to the education criterion $(F(6,357)=2.765, p<0.05)$, whereas according to the age criterion, no such differences exist. Except for that, it was also established that there were differences among the respondent groups according to the age criterion and the tradition criterion $(\mathrm{F}(6,357)=2.599, \mathrm{p}<0.05)$, whereas according to the education criterion, there are no statistically significant differences.

Table 5 The results of the single factor analysis of the variance

\begin{tabular}{lcccc}
\hline & \multicolumn{2}{c}{ Cosmopolitanism } & \multicolumn{2}{c}{ Tradition } \\
\cline { 2 - 5 } & Fvalue & Sig. & F value & Sig. \\
\hline Age & 1.415 & 0.208 & 2.599 & 0.045 \\
\hline Education & 2.765 & 0.024 & 1.604 & 0.212 \\
\hline
\end{tabular}

Source: Author

By a post-hoc analysis and by applying the Tukey HSD test, it was determined that there were groups among which there are the aforementioned differences. When cosmopolitanism is concerned, these tests revealed that there were statistically significant differences among the respondents with an elementary degree of education ( $\mathrm{AS}=4.725, \mathrm{SD}=1.596)$ and the respondents with a postgraduate degree $(\mathrm{AS}=5.621, \mathrm{SD}=1.099$ ) and a Ph.D. degree (AS $=5.640, S D=1.352)$. As far as traditional values are concerned, there are statistically significant differences among the groups of the respondents who are from 19 to 24 years of age (AS $=5.283, \mathrm{SD}=1.171)$, from 40 to 49 years of age (AS = $5.940, \mathrm{SD}=0.977)$ and the group of the respondents older than $60(\mathrm{AS}=6.233, \mathrm{SD}=1.069)$.

Finally, we examined the statistical significance of the differences between the attitudes of the male and the female sexes towards cosmopolitanism and tradition by applying the t-test of independent samples. The obtained results, which are given in Table 6, show that there are statistically significant differences between the attitudes of the men and the women in the case of both observed factors. In addition, it can be noticed that the women exhibit a higher level of cosmopolitanism $(\mathrm{AS}=5.296, \mathrm{SD}=1.201)$ than the men $(\mathrm{AS}=4.888, \mathrm{SD}=1.254)$, whereas simultaneously they also exhibit a higher level of traditional values (AS $=5.820, \mathrm{SD})$ compared to the men $(\mathrm{AS}=5.570, \mathrm{SD}=$ $1.314)$. 
Table 6 The t-test results for the two independent samples

\begin{tabular}{lcccccc}
\hline & \multicolumn{2}{c}{ Males } & \multicolumn{2}{c}{ Females } & $\mathrm{t}$ & \multirow{2}{*}{ Sig. } \\
\cline { 2 - 5 } & AS & SD & AS & SD & value & \\
\hline $\begin{array}{l}\text { Cosmo- } \\
\text { polita- } \\
\text { nism }\end{array}$ & 4.888 & 1.254 & 5.296 & 1.201 & -3.162 & 0.002 \\
Tradition & 5.570 & 1.314 & 5.820 & 1.122 & -1.953 & 0.050 \\
\hline
\end{tabular}

Source: Author

\section{CONCLUSION}

This study was aimed at analyzing the factors that influence certain aspects of consumers' behavior in relation to fast food restaurants, and those aspects are the evaluations of products and behavioral intentions. Cosmopolitanism and consumers' tradition are the factors whose impact was analyzed.

The results of this research study indicate the positive and statistically significant influence of the cosmopolitanism factor on the evaluations of the products and services of foreign fast food restaurants. The analysis of the impact of tradition on the evaluation of products and services shows that tradition has a positive, statistically significant influence on the evaluations of domestic fast food restaurants.

In addition to the above-mentioned results, the analysis has not proven that cosmopolitanism has a negative impact on the evaluation of the products and services of domestic restaurants or that tradition has a negative impact on the evaluation of foreign fast food restaurants, either. Such results indicate that the people who are cosmopolitan-oriented do not necessarily have to be negatively inclined towards domestic products and services. Moreover, possessing traditional values does not necessarily imply negative attitudes towards foreign products and services. The results of the conducted research show that traditional consumers can be a potential segment not only for domestic fast food restaurants, but for international ones as well. Also, cosmopolitan-oriented consumers can be a potential segment not only for foreign fast food restaurants, but also for domestic ones.

The significance and contribution of this research study are reflected in the filling of the gap caused by the lack of papers dedicated to this research problem in the Republic of Serbia, generally in the service sector, and especially in the fast food restaurants sector. The results of the conducted research can be significant for business practice and for the management of fast food restaurants as they provide an analysis of consumers' attitudes towards the evaluation of the products and services present in restaurants and their intentions regarding a future behavior crucial for the success of the business activities carried out by international fast food chains. This analysis is also important because it can help formulate a strategy for promoting domestic fast food restaurants by putting a special emphasis on traditional aspects, which will have a positive impact on the attitudes of those consumers who value these values. Conversely, if the management of domestic restaurants want to attract the consumers who are characterized by cosmopolitanism, the offer and promotion of these restaurants should be adapted to the current world trends and products that can be found in foreign fast food restaurants.

On the other hand, international fast food chains could benefit from the results of the survey in terms of the formulation and creation of their own offer and promotion. Although it is clear that the consumers who are cosmopolitan-oriented are of great importance to international restaurants, traditional consumers could also be attracted by international restaurants by introducing the products adapted to the tastes and preferences of domestic, local consumers into their respective offers.

Also, the results of the research indicate that there are significant differences among the attitudes of the different consumer groups, which may be important for defining the target segments when formulating strategies for the promotion of fast food restaurants and their service offer. 
The conducted research has certain limitations. Having in mind the fact that the survey was carried out in the territory of the city of Kragujevac and the neighboring cities, the results show the attitudes of the consumers from that region, which may be a problem in terms of the generalization of the results and their application in other regions and countries. In order to achieve a greater degree of generalization, future research should certainly include a greater number of markets and consumers, which would also provide opportunities for a broader comparative analysis. Another limitation of this research study is also the fact that it does not include the other variables that can affect consumers' attitudes towards foreign and domestic fast food restaurants, such as materialism, ethnocentrism or consumer animosity, and the other variables that are usually used in similar research studies. The directions of future research can include an analysis of the direct or mediatory impact of additional factors (such as ethnocentrism, involvement in the decisionmaking process of purchasing and materialism) on consumers' evaluations and intentions regarding the use of the services of domestic and foreign fast food restaurants.

\section{REFERENCES}

Ajzen, I. (1991). The theory of planned behavior. Organizational Behavior And Human Decision Processes, 50(2), 179-211. doi: org/10.1016/0749-5978(91)90020-T

Ajzen, I., \& Fishbein, M. (1980). Understanding attitudes and predicting social behavior. Englewood Cliffs, NJ: PrenticeHall.

Alden, D. L., Steenkamp, J. E., \& Batra, R. (1999). Brand positioning through advertising in Asia, North America, and Europe: The role of global consumer culture. Journal of Marketing, 63(1). 75-87.

Cleveland, M., \& Laroche, M. (2007). Acculturation to the global consumer culture: Scale development and research paradigm. Journal of Business Research, 60(3), 249-259. doi: 10.1016/j.jbusres.2006.11.006
Cleveland, M., Laroche, M., \& Hallab, R. (2013). Globalization, culture, religion, and values: Comparing consumption patterns of Lebanese Muslims and Christians. Journal Of Business Research, 66(8), 958-967. doi: 10.1016/j.jbusres.2011.12.018

Cleveland, M., Laroche, M., \& Papadopoulos, N. (2009). Cosmopolitanism, consumer ethnocentrism, and materialism: An eight-country study of antecedents and outcomes. Journal of International Marketing, 17(1), 116-146. doi: org/10.1509/jimk.17.1.116

Cleveland, M., Papadopoulos, N., \& Laroche, M. (2011). Identity, demographics, and consumer behaviors. International Marketing Review, 28(3), 244-266. doi: org/10.1108/02651331111132848

Costa, C., Carneiro, J., \& Goldszmidt, R. (2016). A contingent approach to country-of-origin effects on foreign products evaluation: Interaction of facets of country image with product classes. International Business Review, 25, 10661075. doi: 10.1016/j.ibusrev.2016.01.003

Field, A. (2000). Discovering Statistics Using SPSS for Windows. Thousand Oaks, CA: Sage Publication.

Fishbein, M., \& Ajzen, I. (1975). Belief, Attitude, Intention and Behavior: an Introduction to Theory and Research. Boston, Massachusetts: Addison-Wesley.

Grünhagen, M., Dant, R. P., \& Zhu, M. (2012). Emerging consumer perspectives on American franchise offerings: Variety seeking behavior in China. Journal of Small Business Management, 50(4), 596-620. doi. org/10.1111/ j.1540-627X.2012.00368.x

Hong, S.-T., \& Wyer, R. S. Jr. (1989). Effects of Countryof-Origin and Product-Attribute Information on ProductEvaluation: An Information Processing Perspective. Journal of Consumer Research, 16(2), 175-87.

Jin, Z., Lynch, R., Attia, S., Chansarkar, B., Gülsoy, T., Lapoule, P., \& Ungerer, M. (2015). The relationship between consumer ethnocentrism, cosmopolitanism and product country image among younger generation consumers: The moderating role of country development status. International Business Review, 24(3), 380-393. doi: 10.1016/j.ibusrev.2014.08.010

Josiassen, A., \& Harzing, A.-W. (2008). Descending from the ivory tower: Reflections on the relevance and future of country of-origin research. European Management Review, 5(4), 264-270. doi: 10.1057/emr.2008.19 
Kim, E., Ham, S., Yang, I., \& Choi, J. (2013). The roles of attitude, subjective norm, and perceived behavioral control in the formation of consumers' behavioral intentions to read menu labels in the restaurant industry. International Journal of Hospitality Management, 35(0), 203213. doi: 10.1016/j. ijhm.2013.06.008

Laroche, M., Papadopoulos, N., Heslop, L., \& Mourali, M. (2005). The influence of country image structure on consumer evaluations of foreign products. International Marketing Review, 22(1), 96-115. doi: org/10.1108/02651330510581190

Magnusson, P., Westjohn, S., \& Zdravkovic, S. (2011). What? I thought Samsung was Japanese: Accurate or not, perceived country of origin matters. International Marketing Review, 28(5), 454-472. doi: org/10.1108/02651331111167589

Manrai, L., Lascu, D.-N., \& Manrai, A. (1998). Interactive effects of country of origin and product category on product evaluations. International Business Review, 7(6), 591-615.

McCall, M., \& Lynn, A., (2008). The effects of restaurant menu item descriptions on perceptions of quality, price and purchase intentions. Journal of Foodservice Business Research. 11(4), 439-445. doi: org/10.1080/15378020802519850

Nijssen, E. J., \& Douglas, S. P. (2008). Consumer worldmindedness, social-mindedness, and store image. Journal Of International Marketing, 16(3), 84-107. doi: 10.1509/jimk.16.3.84

Nunnally, J. C. (1978). Introduction to Psychological Measurement. New York, NY: McGraw-Hill.

Oliver, R. L. (1996). Satisfaction: A Behavioral Perspective on the Consumer. New York, NY: McGraw-Hill.

Peterson, R. A., \& Jolibert, A. J. P. (1995). A meta-analysis of country-of-origin effects. Journal of International Business Studies, 26(4), 883-900. doi.org/10.1057/palgrave.jib

Pharr, J. M. (2005). Synthesizing country-of-origin research from the last decade: Is the concept still salient in an era of global brands? Journal of Marketing Theory and Practice, 13(4), 34-45. doi.org/10.1080/10696679.2005.11658557
Riefler, P., \& Diamantopoulos, A. (2009). Consumer cosmopolitanism: Review and replication of the CYMYC scale. Journal of Business Research, 62(4), 407-41. doi. org/10.1016/j.jbusres.2008.01.041

Riefler, P., Diamantopoulos, A., \& Siguaw, J. A. (2012). Cosmopolitan consumers as target group for segmentation. Journal of International Business Studies, 43(3), 285-305. doi.org/10.1057/jibs.2011.51

Schwartz, S. H. (1992). Universals in the content and structure of values: Theory and empirical tests in 20 countries. In M. Zanna (Ed.). Advances in experimental social psychology (pp. 1-65), 25, New York, NY: Academic Press. doi.org/10.1016/S0065-2601(08)60281-6

Schwartz, S. H. (1994). Are there universal aspects in the content and structure of values? Journal of Social Issues, 50(4), 19-45. doi: 10.1111/j.1540-4560.1994.tb01196.x

Schwartz, S., Cieciuch, J., Vecchione, M., Davidov, E., Fischer, R., Beierlein, C., Ramos, A., Verkasalo, M. Lonnqvist, J., Demirutku, K., Dirilen-Gumus, O., \& Konty, M. (2012). Refining the theory of basic individual values. Journal Of Personality And Social Psychology, 103(4), 663-688. doi: 10.1037/a0029393

Sharma, P. (2011). Country of origin effects in developed and emerging markets: Exploring the contrasting roles of materialism and value consciousness. Journal of International Business Studies, 42(2), 285-306. doi:10.1057/ jibs. 2010.16

Skrbis, Z., Kendall, G., \& Woodward, I. (2004). Locating cosmopolitanism: Between humanist ideal and grounded social category. Theory, Culture \& Society, 21(6), 115-136. doi: 10.1177/0263276404047418

Steenkamp, J.-B. E. M., \& de Jong, M. G. (2010). A Global Investigation into the constellation of consumer attitudes toward global and local products. Journal Of Marketing, 74(6), 18-40. doi: org/10.1509/jmkg.74.6.18

Steenkamp, J.-B. E. M., Hofstede, F. T., \& Wedel, M. (1999). A cross-national investigation intothe individual and national cultural antecedents of consumer innovativeness. Journal of Marketing, 63(2), 55-69. doi: $10.2307 / 1251945$ 
Tajfel, H. (1978). Social categorization, social identity and social comparison. In H. Tajfel, (Ed.). Differentiation Between Social Groups: Studies in the Social Psychology of Intergroup Relations (pp. 61-76). London, UK: Academic Press.

Tajfel, H., \& Turner, J. C. (1986). The social identity theory of intergroup behavior. Psychology of Intergroup Relations, $5,7-24$.

Verlegh, P. W. J. (2007). Home country bias in product evaluation: The complementary roles of economic and socio-psychological motives. Journal of International Business Studies, 38(3), 361-73. doi: org/10.1057/palgrave. jibs. 8400269

Verlegh, P. W. J., \& Steenkamp, J.-B. E. M. (1999). A review and meta-analysis of country-of-origin research. Journal of Economic Psychology, 20(5), 521-546.
Wang, C., \& Mattila, A. S. (2015). The impact of servicescape cues on consumer prepurchase authenticity assessment and patronage intentions to ethnic restaurants. Journal Of Hospitality \& Tourism Research, 39(3), 346-372. doi: $10.1177 / 1096348013491600$

Westjohn, S. A., Arnold, M. J., Magnusson, P., \& Reynolds, K. (2016). The influence of regulatory focus on global consumption orientation and preference for global versus local consumer culture positioning. Journal of International Marketing, 24(2), 22-39. doi: 10.1509/ jim.15.0006

Zeugner-Roth, K. P., Žabkar, V., \& Diamantopoulos, A. (2015). Consumer ethnocentrism, national identity, and consumer cosmopolitanism as drivers of consumer behavior: A social identity theory perspective. Journal Of International Marketing, 23(2), 25-54. doi: 10.1509/ jim.14.0038

http://www.ibisworld.com/industry/global/global-fastfood-restaurants.html

Received on $21^{\text {st }}$ June 2017, after two revisions, accepted for publication on $23^{\text {rd }}$ August 2017. Published online on $25^{\text {th }}$ August 2017.

Srdjan Sapic is an Associate Professor at the Faculty of Economics, University of Kragujevac, Kragujevac, the Republic of Serbia. He teaches the courses in International Marketing, International Business and Management and Marketing Services. He received his PhD degree from the Faculty of Economics, University of Kragujevac. The areas of his scientific interest are the international marketing environment, marketing services, intercultural marketing and the forms of internationalization. 


\title{
EFEKTI KOSMOPOLITIZMA I TRADICIJE NA PROCENE I NAMERE KORISNIKA USLUGA RESTORANA BRZE HRANE
}

\author{
Srđan Šapić* \\ Ekonomski fakultet Univerziteta u Kragujevcu
}

U savremenim uslovima života, potrošači kada ne žele da jedu kod kuće imaju sve veći izbor različitih vrsta restorana. Restorani brze hrane predstavljaju jednu od opcija. Pored domaćih restorana brze hrane, primetan je razvoj globalnih lanaca restorana. Svrha ovog rada je identifikovanje faktora koji utiču na procene proizvoda i usluga i namere korisnika u pogledu korišćenja usluga restorana brze hrane. $S$ tim u vezi bitna je analiza faktora kosmopolitizma i tradicije. Kosmopolitizam kao spremnost ljudi da sarađuju sa drugim kulturama i tradicija kao odraz poštovanja običaja i ideja koje pojedincima nameću njihova kultura ili religija, utiču na namere potrošača i spremnost da koriste usluge stranih restorana brze hrane. U skladu s tim, cilj istraživanja je utvrđivanje da li i na koji način kosmopolitizam i tradicija utiču na procene proizvoda i usluga i namere korisnika stranih lanaca restorana i domaćih restorana brze hrane lokalnog i porodičnog karaktera. Rezultati sprovedenog empirijskog istraživanja ukazuju da kosmopolitizam potrošača utiče pozitivno na procene proizvoda i usluga stranih restorana, kao i da tradicija utiče pozitivno na procene proizvoda i usluga domaćih restorana brze hrane.

Ključne reči: kosmopolitizam, tradicija, procena proizvoda i usluga, namere korisnika u ponašanju, restorani brze hrane

JEL Classification: M31, L83

\section{UVOD}

Tokom poslednjih decenija, dolazi do značajanog rasta $\mathrm{u}$ industriji restoraterstva na globalnom nivou. Samim tim, izbor koji potrošači imaju kada žele da ,jedu napolju” se stalno povećava, a konkurencija među restoranima različitih vrsta raste. Ovaj koncept restorana nastao je u Sjedinjenim Američkim Državama početkom 1950-ih, a danas

* Korespondencija: S. Šapić, Ekonomski fakultet Univerziteta u Kragujevcu, Đ. Pucara 3, 34000 Kragujevac, Republika Srbija; e-mail: ssapic@kg.ac.rs je prerastao u globalnu industriju sa godišnjim prihodima vrednim preko 580 milijardi dolara, više od 13 miliona zaposlenih i godišnjom stopom rasta od 2,8\% (IBISWorld). Restorani brze hrane su najčešce deo globalnih lanaca restorana brze hrane ili franšiza, a njihovi proizvodi su u najvećoj meri deo standardizovanog proizvodnog programa, sa određenim lokalnim varijacijama. Neki od najpoznatijih globalnih lanaca restorana brze hrane su McDonald's, Subway, KFC, Pizza Hut, Burger King i drugi. Većina ovih restorana prisutna je na tržištima velikog dela Evrope već nekoliko decenija, pa i na 
tržištu Republike Srbije (RS), u nešto kraćem periodu. Konkretno, prvi McDonald's restoran u Beogradu otvoren je 1988. Pored ovih globalnih lanaca restorana brze hrane, na tržištu RS prisutan je i veliki broj različitih domaćih restorana brze hrane. Ovi restorani su najčešće lokalnog i porodičnog karaktera (pekare, ćevabdžinice, picerije i sl.), nisu deo franšiznih sistema i potrošačima nude različite vrste proizvoda specifičnih za određena područja i prilagođenih lokalnim ukusima.

U uslovima izražene konkurencije i borbe za potrošače, za menadžment restorana brze hrane je vrlo važno razumevanje faktora koji utiču na ponašanje i namere potrošača $u$ vezi sa korišćenjem usluga domaćih i stranih restorana brze hrane. U marketing literaturi, istraživači su otkrili i analizirali brojne faktore koji utiču na ponašanje potrošača i odluke o kupovini različitih vrsta domaćih i stranih proizvoda (Verlegh, 2007; Sharma, 2011; Zeugner-Roth, Žabkar, \& Diamantopoulos, 2015). Međutim, primećuje se manjak ovakvih studija kada se radi o uslužnom sektoru, a studija na ovu temu, pogotovo vezanih za restorane brze hrane gotovo i da nema. Radi prevazilaženja primećenog istraživačkog jaza, u ovom radu analiziran je uticaj dva faktora, kosmopolitizma i tradicije potrošača, na procene usluga i proizvoda i namere $u$ ponašanju potrošača domaćih i stranih restorana brze hrane.

Predmet istraživanja ovog rada jeste analiza ponašanja korisnika usluga restorana brze hrane, kao i analiza efekata zemlje porekla samih restorana. Naime, osnovna pretpostavka istraživanja jeste da zemlja porekla restorana brze hrane ima uticaj na procene i namere potrošača. U skladu s tim, predmet istraživanja jeste analiza načina na koji kosmopolitizam i tradicija utiču na formiranje procena i namera potrošača prema korišćenju usluga stranih (ponuda standardizovanog proizvodnog programa, sa određenim lokalnim varijacijama) i domaćih (različite vrste proizvoda specifičnih za određena područja i prilagođenih lokalnim ukusima) restorana brze hrane.

Osnovni cilj istraživanja je da putem konceptualnog modela predvidi uticaj kosmopolitizma i tradicije na procene usluga i proizvoda $u$ restoranima brze hrane i njihove namere prema korišćenju usluga ovih restorana.
Istraživanje je sprovedeno na teritoriji Kragujevca i okolnih gradova. Ispitivanje navedenih veza izvršeno je putem anketnog metoda. U okviru istraživanja, korišćene su deskriptivna statistika, eksplorativna faktorska analiza i analiza pouzdanosti, kojima je potvrđeno postojanje dva faktora i njihova interna konzistentnost. Testiranje hipoteza o uticaju faktora na procene i namere korisnika usluga restorana brze hrane izvršeno je putem višestruke i proste regresione analize. Ispitivanje statistički značajnih razlika između grupa ispitanika u uzorku izvršeno je korišćenjem jednofaktorske analize varijanse i t testa nezavisnih uzoraka.

Rad je strukturiran $u$ pet celina. Nakon uvodnih razmatranja, predstavljena je teorijska konceptualizacija posmatranih faktora koji utiču na procene i namere potrošača, a to su kosmopolitizam i tradicija. Pored toga, analiziran je pojam efekata zemlje porekla i uticaj ovog efekta na procene $i$ namere koje potrošači formiraju $u$ vezi sa kupovinom proizvoda i korišćenjem usluga domaćih i međunarodnih kompanija. U ovoj celini su definisane i osnovne hipoteze istraživanja, na osnovu predstavljenih teorijskih razmatranja i rezultata prethodnih istraživanja. U narednoj celini rada je objašnjen konceptualni model istraživanja, i metode istraživanja koje su korišćene u radu. Glavni rezultati empirijskog istraživanja, na osnovu kojih su testirane postavljene hipoteze, predstavljeni su u četvrtoj celini. Poslednja celina rada podrazumeva analizu rezultata istraživanja, zaključna razmatranja i povezanost sa rezultatima prethodnih istraživanja. Ukazano je na osnovna ograničenja istraživanja kao i na potencijalne buduće pravce $u$ istraživanju opisanog problema.

\section{PREGLED LITERATURE I DEFINISANJE HIPOTEZA}

\section{Kosmopolitizam potrošača}

Aktuelni procesi globalne integracije uključuju, pored uočljivih procesa međunarodne trgovine, političke kooperacije i međunarodnih putovanja, i razvoj 
socio-psihološke percepcije sveta kao jedinstvenog mesta (Westjohn, Arnold, Magnusson \& Reynolds, 2016). Posledica ovoga je da ljudi sve više formiraju svoje stavove imajući u vidu globalnu dostupnost multinacionalnih proizvoda i brendova, što dovodi do nastajanja homogene globalne potrošačke kulture (Alden, Steenkamp \& Batra, 1999; Cleveland \& Laroche, 2007). Jedna od dimenzija ponašanja potrošača, koja nastaje u vezi sa prilagođavanjem globalnoj potrošačkoj kulturi, je kosmopolitizam potrošača (Cleveland \& Laroche, 2007).

Iako se termin kosmopolitizam često vezivao za svaku osobu koja se puno kreće u globalnim okvirima, sveobuhvatnije je posmatrati ga kao konkretan skup verovanja, stavova i kvaliteta koji poseduju određeni ljudi, uključujući spremnost da sarađuju sa drugim kulturama, kao i nivo kompetencija prema njima (Cleveland \& Laroche, 2007). Opširnije određenje pojma daju P. Riefler, A. Diamantopoulos i J. A. Siguaw $(2012,287)$, prema kojima se potrošački kosmopolitizam može posmatrati kao mera u kojoj potrošač:

- pokazuje otvorenost prema drugim zemljama i kulturama,

- ceni raznolikost koja je posledica dostupnosti proizvoda različitog nacionalnog i kulturalnog porekla, i

- ima pozitivnu naklonost ka potrošnji proizvoda iz različitih zemalja.

Dakle, potrošači sa razvijenim kosmopolitizmom poseduju svest koja je otvorena prema svetu i kulturalnim razlikama (Skrbis, Kendall \& Woodward, 2004), pozitivne stavove prema dostupnosti proizvoda iz različitih zemalja, i stalno uživaju u proizvodima, mestima i iskustvima koji dolaze iz različitih kultura (Riefler \& Diamantopoulos, 2009).

Potrošački kosmopolitizam je predmet studija u kojima se često posmatra kao varijabla preko koje se može predvideti namera potrošača da kupe određene lokalne i globalne proizvode (Cleveland, Laroche \& Papadopoulos, 2009; Riefler \& Diamantopoulos, 2009; Zeugner-Roth, Žabkar \& Diamantopoulos,
2015). Tako su K. P. Zeugner-Roth, V. Žabkar i A. Diamantopoulos (2015) dokazali da kosmopolitizam utiče pozitivno na kupovinu stranih proizvoda, ali i na namere potrošača i spremnost da kupe ovu vrstu proizvoda. Slično istraživanje je dokazalo da izražen nacionalni identitet $u$ velikoj meri utiče na konzumiranje lokalnih proizvoda $\mathrm{u}$ domenu hrane, a kosmopolitizam u slučaju globalnih proizvoda (Cleveland, Papadopoulos \& Laroche 2011). Međutim, mali je broj studija koje u fokusu imaju kosmopolitizam u uslužnom sektoru i njegov uticaj na ponašanje potrošača (Nijssen \& Douglas, 2008; Wang \& Mattila, 2015). Na osnovu navedenih istraživanja, može se pretpostaviti da će potrošači sa izraženim kosmopolitizmom preferirati korišćenje usluga stranih restorana brze hrane, pošto su oni pretežno deo globalno prisutnih lanaca brze hrane. $S$ druge strane, ovi potrošači će, verovatno, formirati negativne percepcije o proizvodima i uslugama lokalnih, tj. domaćih restorana brze hrane. U skladu sa tim, moguće je formulisati sledeće hipoteze:

H1a: Kosmopolitizam ima statistički značajan i negativan uticaj na procenu proizvoda i usluga domaćih restorana brze hrane.

H1b: Kosmopolitizam ima statistički značajan i pozitivan uticaj na procenu proizvoda i usluga stranih restorana brze hrane.

\section{Tradicija}

Pojam tradicije se odnosi na poštovanje, prihvatanje i posvećenost običajima i idejama koje pojedincima nameću njihova kultura ili religija (Schwartz, 1992; 1994). Pored toga, tradicionalne vrednosti podrazumevaju skromnost, poniznost i umerenost u životu, kao i posvećenost vrednostima i načinu života koji su prihvaćeni $u$ društvu. Tradicija kao osobina ličnosti odlikuje pojedince koji odobravaju konzervativni način odgajanja dece, poseduju tradicionalne vrednosti, religiozna uverenja, poštovanje prema starijima, kao i konvencionalne ispravne osobine i ponašanje (Grünhagen, Dant \& Zhu, 2012). Prema klasifikaciji koju predlaže S. H. Schwartz (1992), tradicija predstavlja jednu od deset osnovnih ličnih vrednosti koje se mogu 
klasifikovati u četiri grupe vrednosti višeg reda. Grupa viših vrednosti kojoj pripada tradicija odnosi se na očuvanje, što podrazumeva samo-ograničenje, red i izbegavanje promena. Ciljevi ovih vrednosti su održavanje i očuvanje kulturalnih, porodičnih i religijskih tradicija (Schwartz, Cieciuch, Vecchione, Davidov, Fischer, Beierlein, Ramos, Verkasalo, Lonnqvist, Demirutku, Dirilen-Gumus \& Konty, 2012). Vrednosti očuvanja, pored tradicije, obuhvataju konformizam, sigurnost i suprotstavljanje potrošača promenama, što može značiti da će potrošači koji pridaju značaj tradiciji preferirati domaće restorane, u odnosu na inostrane, koji predstavljaju novinu na tržištu, i promenu $\mathrm{u}$ odnosu na postojeće, tradicionalne restorane brze hrane u Republici Srbiji.

Istraživanje koje su sproveli J.-B. E. M. Steenkamp i M. G. de Jong (2010) pokazalo je da pridavanje značaja tradiciji, kao opštoj vrednosti pojedinaca, utiče negativno na stavove potrošača o globalnim, a pozitivno na stavove o lokalnim proizvodima. Pored toga, J.-B. E. M. Steenkamp, F. T. Hofstede i M. Wedel (1999) su dokazali da vrednosti očuvanja, među kojima je i tradicija, utiču negativno na inovativnost potrošača u pogledu prihvatanja novih, inostranih proizvoda na tržištu. I drugi autori su došli do sličnih rezultata. M. Cleveland, M. Laroche i R. Hallab (2013) su utvrdili da tradicija ima negativan uticaj na stavove potrošača o globalizaciji i prihvatanju globalne potrošačke kulture. Pored ovih generalnih studija, studije koje se odnose na istraživanje uticaja tradicije na ponašanje potrošača u uslužnom sektoru su veoma retke. Na osnovu teorijskog određenja pojma tradicije i rezultata empirijskih istraživanja, može se pretpostaviti da tradicionalne vrednosti utiču pozitivno na percepcije potrošača o domaćim restoranima brze hrane, a negativno na percepcije potrošača o proizvodima i uslugama stranih restorana brze hrane, pa se mogu formulisati sledeće hipoteze:

H2a: Tradicija ima statistički značajan i pozitivan uticaj na procenu proizvoda i usluga domaćih restorana brze hrane.

H2b: Tradicija ima statistički značajan i negativan uticaj na procenu proizvoda i usluga stranih restorana brze hrane.

\section{Efekti zemlje porekla - procena proizvoda i namere $u$ ponašanju}

Efekti zemlje porekla proizvoda su predmet izučavanja u naučnoj literaturi već nekoliko decenija. Navedeni efekti podrazumevaju da određeni potrošači pokazuju pozitivne ili negativne predispozicije prema kupovini različitih proizvoda, u zavisnosti od zemlje porekla sa kojom ih povezuju (Verlegh \& Steenkamp, 1999; Josiassen \& Harzing, 2008; Magnusson, Westjohn \& Zdravkovic, 2011). Analizom relevantne literature iz ove oblasti može se doći do zaključka da zemlja porekla proizvoda i usluga utiče na procenu proizvoda i kupovno ponašanje potrošača (Peterson \& Jolibert, 1995; Verlegh \& Steenkamp, 1999; Pharr, 2005; Sharma, 2011). U okviru ovog istraživanja, kao efekti uticaja zemlje porekla restorana brze hrane, razmatrani su evaluacija proizvoda i usluga, kao i njihov uticaj na namere $u$ ponašanju potrošača, $u$ pogledu korišćenja usluga domaćih i stranih restorana brze hrane.

Zemlja porekla služi kao veoma važna osnova za procene koje potrošači formiraju o proizvodima i uslugama (Hong \& Wyer, 1989). Veliki broj autora smatra da zemlja porekla proizvoda i/ili usluga i njen imidž utiču pozitivno ili negativno na procene proizvoda koje dolaze iz tih zemalja i ovo pitanje je predmet istraživanja brojnih studija (Laroche, Papadopoulos, Heslop \& Mourali, 2005; Costa, Carneiro \& Goldszmidt, 2016). Procena proizvoda, prema M. Laroche i ostalima (2005) se odnosi na skup stavova koji potrošač ima o proizvodu, a koji se ispoljava putem dopadanja, zadovoljstva usled posedovanja proizvoda, kao i želje za kupovinom. Potrošači pribegavaju analizi određenih znakova prilikom formiranja procene proizvoda i usluga. Ovi znaci mogu biti unutrašnje, fizički opipljive, karakteristike proizvoda (dizajn, oblik, boja), kao i spoljašnje, u manjoj meri opipljive karakteristike proizvoda (cena, garancija, brend i zemlja porekla proizvoda) (Manrai et al, 1998; Verlegh \& Steenkamp, 1999). Druga grupa znakova dobija na značaju kada potrošači ne mogu u potpunosti objektivno da procene proizvod. Imajući u vidu nivo neopipljivih elemenata prisutnih u slučaju usluga, može se zaključiti da su oni posebno važni za procene korisnika usluga. 
U cilju analize efekata kosmopolitizma i tradicije na procene i namere potrošača, istraživanje se oslanja na Teoriju socijalnog identiteta (Tajfel, 1978; Tajfel \& Turner, 1986), prema kojoj pojedinci formiraju svoje stavove i ponašanje u skladu sa svojom pripadnošću određenoj grupi. Na osnovu ove teorije, navedeni faktori mogu imati pozitivan ili negativan uticaj na stavove i ponašanje potrošača prema unutrašnjoj grupi, tj. svojoj zemlji, kao i spoljašnjoj grupi, tj. stranim zemljama. U ovom istraživanju, analizira se priroda uticaja navedena dva faktora na stavove i ponašanje potrošača prema domaćim i stranim restoranima brze hrane. Na ovaj način, posmatra se model koji obuhvata značajne faktore za razumevanje načina na koji potrošači donose odluke o korišćenju usluga stranih, odnosno, domaćih restorana brze hrane.

Namere $u$ ponašanju se mogu posmatrati kao poseban oblik verovanja, u kojem je objekat uvek sama osoba, a atribut je uvek ponašanje (Fishbein \& Ajzen, 1975, 12). Slično tome, R. L. Oliver (1996) je definisao namere $u$ ponašanju kao izuzetno visoku verovatnoću iskazivanja određene vrste ponašanja. One se u sažetom obliku mogu opisati kao plan da se izvrši određena vrsta ponašanja. Pored toga, postoji takva povezanost između namera i stvarnog ponašanja, koja podrazumeva da što su jače namere da se preduzme određeni vid ponašanja, to je veća verovatnoća da će ponašanje biti sprovedeno u akciju (Kim, Ham, Yang \& Choi, 2013).

Prilikom istraživanja i izrade konceptualnog modela, korišćeni su neki od osnovnih elemenata Teorije rezonske akcije (Ajzen \& Fishbein, 1980), koja ukazuje na to da stavovi o ponašanju i subjektivne norme utiču na nameru, i utiče na ponašanje potrošača, i Teorije planskog ponašanja (Ajzen, 1991), prema kojima stavovi i procene potrošača utiču na njihove namere $u$ ponašanju, a one $u$ krajnjoj liniji utiču na stvarno ponašanje potrošača. Sličan konceptualni okvir korišćen je u brojnim relevantnim istraživačkim studijama (Riefler \& Diamantopoulos, 2009; ZeugnerRoth et al, 2015). U slučaju ovog istraživanja, namere u ponašanju se analiziraju kroz tri segmenta, a to su namere vezane za isprobavanje, korišćenje usluga i širenje pozitivnih informacija o restoranima brze hrane (McCall \& Lynn, 2008; Sharma, 2011). U skladu sa navedenim teorijskim konceptima, mogu se definisati sledeće hipoteze, koje opisuju vezu između procena i namera potrošača:

H3a: Procene proizvoda i usluga u domaćim restoranima brze hrane imaju pozitivan i statistički značajan uticaj na namere potrošača u pogledu korišćenja usluga ovih restorana.

H3b: Procene proizvoda i usluga u stranim restoranima brze hrane imaju pozitivan i statistički značajan uticaj na namere potrošača u pogledu korišćenja usluga ovih restorana.

\section{ISTRAŽIVAČKI MODEL}

Na osnovu pregleda literature i postavljenih hipoteza može se kreirati konceptualni model istraživanja, kojim su predstavljene veze između datih varijabli. U okviru modela, istražuje se pozitivan uticaj kosmopolitizma i tradicije na procene proizvoda $\mathrm{i}$ usluga domaćih i stranih restorana brze hrane. Pored toga, istražuje se uticaj procena potrošača na namere $\mathrm{u}$ ponašanju potrošača $\mathrm{u}$ pogledu korišćenja usluga navedenih restorana brze hrane. Navedene relacije predstavljene su na Slici 1.

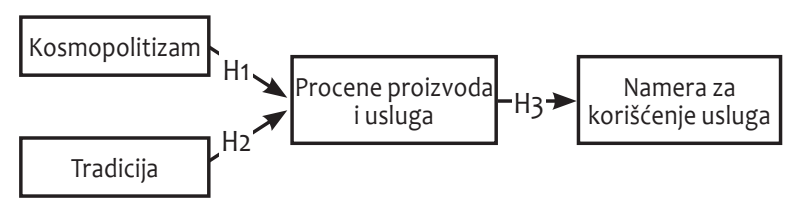

Slika 1 Konceptualni model istraživanja

Izvor: Autor

\section{Metodologija}

Radi utvrđivanja postojanja navedenih veza, sprovedeno je istraživanje putem anketnog metoda, na teritoriji Kragujevca i okolnih gradova. Istraživanjem su prikupljene 364 ankete, na prostom slučajnom uzorku. Anketiranje je obavljeno u periodu 
mart-jun 2017. Podaci su dobijeni putem distribuiranja upitnika u papiru, pri čemu su ispitanici ocenjivali stepen svog slaganja sa navedenim tvrdnjama na sedmostepenoj Likertovoj skali (gde je 1 - izrazito se ne slažem, 7 - izrazito se slažem). Struktura uzorka prema socio-demografskim karakteristikama prikazana je u Tabeli 1.

Tabela 1 Deskriptivna statistika za karakteristike ispitanika

\begin{tabular}{llc}
\hline & & \% ispitanika \\
\hline \multirow{2}{*}{ Pol } & Muški & 45,6 \\
& Ženski & 54,4 \\
\hline \multirow{3}{*}{ Starost } & mlađi od 18 & 4,4 \\
& $19-24$ & 30,4 \\
& $25-29$ & 14,8 \\
& $30-39$ & 14,6 \\
& $40-49$ & 15,4 \\
& $50-59$ & 10,7 \\
& 60 i više od 60 & 9,7 \\
\hline \multirow{5}{*}{ Obrazovanje } & Osnovna škola & 2,2 \\
& Srednja škola & 36,5 \\
& Strukovne studije & 19,3 \\
& Diplomske studije & 13,2 \\
& Poslediplomske studije & 5,1 \\
& Doktorske studije & 1,4 \\
\hline
\end{tabular}

Izvor: Autor

U istraživanju su korišćene četiri varijable, a pripadajuće konstatacije su formulisane $u$ skladu sa pregledom relevantne literature. Kosmopolitizam je meren putem pet konstatacija, preuzetih iz studije čiji su autori Z. Jin, R. Lynch, S. Attia, B. Chansarkar, T. Gülsoy, P. Lapoule i M. Ungerer (2015). Konstatacije vezane za tradiciju preuzete su iz studije čiji su autori
S. Schwartz i drugi (2012). Kao efekti zemlje porekla, procena proizvoda i namere $u$ ponašanju, odnosno, konstatacije vezane za ove varijable, preuzete su iz studije koju je sproveo P. Sharma (2011).

Statistička obrada i analiza podataka izvršena je korišćenjem softverskog paketa SPSS (Statistical Package for Social Sciences, Version 21.0). Pre ispitivanja uticaja određenih varijabli na procene i namere potrošača, korišćenjem eksplorativne faktorske analize (metod glavnih komponenti, varimax rotacija) izvršeno je grupisanje konstatacija u okviru dva faktora, kosmopolitizma i tradicije potrošača. Nakon ove analize, korišćenjem višestruke regresione analize ispitan je uticaj dobijenih faktora na procene proizvoda i usluga, za slučaj domaćih i stranih restorana brze hrane, kao i uticaj procena potrošača na njihove namere $u$ pogledu korišćenja usluga domaćih i stranih restorana brze hrane, putem proste linearne regresije. Za testiranje hipoteza $\mathrm{H} 3 \mathrm{a}$ i $\mathrm{H} 3 \mathrm{~b}$ korišćena je prosta regresiona analiza. Na kraju je ispitana statistička značajnost razlika između srednjih vrednosti pojedinih grupa uzoraka, korišćenjem jednofaktorske analize varijanse i t testa nezavisnih uzoraka.

\section{REZULTATI ISTRAŽIVANJA}

U cilju grupisanja konstatacija iz upitnika u faktore izvršena je eksplorativna faktorska analiza. Ovom analizom su dobijena dva faktora: kosmopolitizam i tradicija potrošača. Pokazatelji koji se moraju uzeti u obzir prilikom ocene opravdanosti primene eksplorativne faktorske analize jesu Bartletov test sferičnosti i Kajzer-Mejer Olkinov (KMO) pokazatelj adekvatnosti uzorka. Vrednost KMO pokazatelja u slučaju ovog istraživanja je 0,802, dok Bartletov test sferičnosti ima statistički značajnu vrednost (Sig. = 0,000), što ukazuje da je upotreba faktorske analize opravdana.

Analizom vrednosti Cronbach-ovog koefecijenta alfa (Cronbach's $\alpha$ ) može se uočiti da oba faktora imaju odgovarajući nivo interne konzistentnosti, viši 
od preporučene vrednosti od 0,7 (Nunnally, 1978). Vrednosti faktorskih opterećenja u svakom faktoru, kao i vrednosti Cronbach-ovog koeficijenta alfa za oba faktora prikazane su u Tabeli 2.

Rezultati deskriptivne statistike prikazani u Tabeli 2 ukazuju na zaključak da su ispitanici više ocene dali grupi konstatacija koje se odnose na tradiciju, $u$ odnosu na konstatacije vezane za kosmopolitizam. Najvišu srednju vrednost ima konstatacija koja se odnosi na značaj porodičnih vrednosti i religijskih običaja (AS $=5,90)$, dok najnižu vrednost ima konstatacija koja ima u fokusu razmenu ideja sa ljudima iz drugih država i kultura (AS $=4,93)$.

U cilju ispitivanja zajedničkog uticaja dobijenih faktora na procene potrošača, korišćena je višestruka linearna regresija, za slučaj domaćih i stranih restorana brze hrane. Rezultati ove analize prikazani su u Tabeli 3. Kada se radi o uticaju kosmopolitizma na procene proizvoda i usluga domaćih restorana brze hrane, može se uočiti da on nema statistički značajan na procene potrošača $(\beta=0,004$, Sig. $=0,939)$. Ovakav rezultat implicira da je hipoteza H1a opovrgnuta. S druge strane, kosmopolitizam ima pozitivan i statistički značajan uticaj na procene koje formiraju potrošači o stranim restoranima brze hrane $(\beta=0,373$, Sig. $=0,000)$, pa je hipoteza H1b potvrđena.

Tabela 3 Rezultati višestruke linearne regresije (zavisna varijabla - Procene potrošača o domaćim i stranim restoranima brze hrane)

\begin{tabular}{|c|c|c|c|c|c|c|}
\hline \multirow[b]{3}{*}{ Varijabla } & \multicolumn{6}{|c|}{ Procene potrošača } \\
\hline & \multicolumn{3}{|c|}{$\begin{array}{c}\text { Domaći restorani } \\
\text { brze hrane }\end{array}$} & \multicolumn{3}{|c|}{$\begin{array}{c}\text { Strani restorani brze } \\
\text { hrane }\end{array}$} \\
\hline & $\beta$ & Sig. & VIF & $\beta$ & Sig. & VIF \\
\hline $\begin{array}{l}\text { Kosmo- } \\
\text { politizam }\end{array}$ & 0,004 & 0,939 & 1,020 & 0,373 & 0,000 & 1,018 \\
\hline Tradicija & 0,321 & 0,000 & 1,020 & $-0,130$ & 0,807 & 1,018 \\
\hline
\end{tabular}

Izvor: Autor

Tabela 2 Rezultati eksplorativne faktorske analize

\begin{tabular}{|c|c|c|c|c|}
\hline Konstatacije & $\begin{array}{l}\text { Factor } \\
\text { loading }\end{array}$ & $\begin{array}{l}\text { Cronbach's } \\
a\end{array}$ & AS & SD \\
\hline Kosmopolitizam & & 0,887 & & \\
\hline Uživam u razmeni ideja sa ljudima iz drugih država i kultura. & 0,798 & & 4,93 & 1,617 \\
\hline Zainteresovan sam da učim o ljudima iz drugih zemalja. & 0,884 & & 5,24 & 1,538 \\
\hline $\begin{array}{l}\text { Volim da provodim vreme s ljudima iz drugih država, da bih naučio o } \\
\text { njihovim pogledima i pristupu životu. }\end{array}$ & 0,897 & & 5,04 & 1,503 \\
\hline $\begin{array}{l}\text { Volim da posmatram ljude iz drugih država, zato što mogu da } \\
\text { naučim nešto od njih. }\end{array}$ & 0,851 & & 5,15 & 1,398 \\
\hline Volim da učim kako drugi pristupaju životnim izazovima. & 0,711 & & 5,20 & 1,408 \\
\hline Tradicija & & 0,866 & & \\
\hline Važno mi je održavanje tradicionalnih vrednosti i uverenja. & 0,852 & & 5,46 & 1,430 \\
\hline Porodične vrednosti i religijski običaji su mi bitni. & 0,899 & & 5,90 & 1,334 \\
\hline Jako cenim tradicionalne vrednosti u svojoj kulturi. & 0,907 & & 5,76 & 1,351 \\
\hline Bartletov test sferičnosti & & Sig. $=0,000$ & & \\
\hline KMO & & 0,802 & & \\
\hline
\end{tabular}


Kada je reč o uticaju tradicije na procene koji potrošači formiraju o proizvodima i uslugama domaćih restorana brze hrane, rezultati ukazuju da postoji pozitivan i statistički značajan uticaj na procene proizvoda i usluga domaćih restorana $(\beta=0,321$, Sig. $=0,000)$, što ukazuje da je hipoteza H2a potvrđena. Pored toga, tradicija ima negativan uticaj na procene potrošača o stranim restoranima, ali ne i statistički značajan uticaj $(\beta=-0,130$, Sig.= 0,807$)$, pa je hipoteza $\mathrm{H} 2 \mathrm{~b}$ opovrgnuta. Pored navedenih rezultata, može se primetiti da multikolinearnost ne predstavlja problem u posmatranim relacijama, s obzirom na to da je vrednost faktora rasta varijanse (VIF) u svim slučajevima manja od preporučene vrednosti od 5 (Field, 2000). Može se uočiti da kosmopolitizam ima nešto izraženiji uticaj na procene proizvoda i usluga stranih restorana, $\mathrm{u}$ odnosu na uticaj koji tradicija ima na procene koje potrošači formiraju u vezi sa proizvodima i uslugama domaćih restorana brze hrane.

U skladu sa ostalim postavljenim hipotezama ispitan je uticaj koji procene potrošača imaju na njihove namere $u$ pogledu budućeg ponašanja. Rezultati ove analize predstavljeni su u Tabeli 4. Kada se posmatra uticaj procena proizvoda i usluga na namere potrošača u pogledu korišćenja usluga domaćih restorana brze hrane može se uočiti da postoji izražen, pozitivan i statistički značajan uticaj $(\beta=0,566$, Sig. $=0,000)$, pa je hipoteza H3a potvrđena.

Tabela 4 Rezultati linearne regresije (zavisna varijabla - Namere potrošača u pogledu korišćenja usluga domaćih i stranih restorana brze hrane)

\begin{tabular}{lcccccc}
\hline & \multicolumn{3}{c}{$\begin{array}{c}\text { Domaći restorani } \\
\text { brze hrane }\end{array}$} & \multicolumn{3}{c}{$\begin{array}{c}\text { Strani restorani brze } \\
\text { hrane }\end{array}$} \\
\hline Varijabla & $\begin{array}{c}\mathrm{R} \\
\text { Square }\end{array}$ & $\beta$ & Sig. & $\begin{array}{c}\mathrm{R} \\
\text { Square }\end{array}$ & $\beta$ & Sig. \\
\hline $\begin{array}{l}\text { Procene } \\
\text { potrošača }\end{array}$ & 0,366 & 0,566 & 0,000 & 0,432 & 0,657 & 0,000 \\
\hline
\end{tabular}

Izvor: Autor
U slučaju uticaja procena potrošača na namere $u$ pogledu korišćenja usluga stranih restorana brze hrane, utvrđen je veoma visok, pozitivan i statistički značajan uticaj $(\beta=0,657$, Sig. $=0,000)$, što implicira da je hipoteza $\mathrm{H} 3 \mathrm{~b}$ takođe potvrđena. U pogledu odnosa procena i namera potrošača, može se primetiti da je jačina uticaja procena proizvoda i usluga, merena visinom koeficijenta $\beta$, izraženija u slučaju stranih restorana u odnosu na domaće restorane brze hrane.

Pored analiziranih veza ispitano je da li postoje statistički značajne razlike između srednjih vrednosti grupa unutar uzorka. Najpre je putem jednofaktorske analize varijanse (ANOVA) analizirano da li se javljaju statistički značajne razlike u pogledu stavova o kosmopolitizmu i tradiciji između različitih grupa ispitanika, prema kriterijumima starosti i obrazovanja. Rezultati navedene analize, prikazani u Tabeli 5, ukazuju da postoje statistički značajne razlike između grupa ispitanika $u$ pogledu kosmopolitizma, prema kriterijumu obrazovanja $(\mathrm{F}(6,357)=2,765, \mathrm{p}<0,05)$, ali da prema kriterijumu starosti ne postoje. Pored toga, utvrđeno je da postoje razlike između grupa ispitanika prema kriterijumu starosti u pogledu tradicije $(\mathrm{F}(6,357)=2,599, \mathrm{p}<0,05)$, dok prema kriterijumu obrazovanja statistički značajne razlike ne postoje.

Tabela 5 Rezultati jednofaktorske analize varijanse

\begin{tabular}{lcccc}
\hline & \multicolumn{2}{c}{ Kosmopolitizam } & \multicolumn{2}{c}{ Tradicija } \\
\cline { 2 - 5 } & Fvrednost & Sig. & F vrednost & Sig. \\
\hline Starost & 1,415 & 0,208 & 2,599 & 0,045 \\
\hline Obrazovanje & 2,765 & 0,024 & 1,604 & 0,212 \\
\hline
\end{tabular}

Izvor: Autor

Post-hoc analizom i korišćenjem Tukey HSD testa utvrđene su i grupe između kojih se javljaju navedene razlike. Kada je reč o kosmopolitizmu, ovi testovi su pokazali da se statistički značajne razlike javljaju između ispitanika koji imaju osnovni stepen obrazovanja $(\mathrm{AS}=4,725, \mathrm{SD}=1,596)$ i ispitanika koji 
imaju završene poslediplomske (AS = 5,621, $\mathrm{SD}=1,099$ ) i doktorske studije (AS =5,640, $\mathrm{SD}=1,352$ ). $\mathrm{U}$ pogledu tradicionalnih vrednosti, statistički značajne razlike se javljaju između grupe ispitanika starosti od 19-24 godina (AS $=5,283, \mathrm{SD}=1,171$ ), grupe starosti od 40 49 godina ( $\mathrm{AS}=5,940, \mathrm{SD}=0,977)$ i grupe ispitanika starijih od 60 godina $(\mathrm{AS}=6,233, \mathrm{SD}=1,069)$.

Na kraju, ispitana je i statistička značajnost razlika između stavova koje pripadnici muškog i ženskog pola imaju o kosmopolitizmu i tradiciji, putem korišćenja $t$ testa nezavisnih uzoraka. Dobijeni rezultati, prikazani u Tabeli 6, pokazuju da postoje statistički značajne razlike između stavova muškaraca i žena, u slučaju oba posmatrana faktora. Osim toga, može se uočiti da žene odlikuje viši nivo kosmopolitizma (AS = 5,296, $\mathrm{SD}=1,201)$ od muškaraca $(\mathrm{AS}=4,888, \mathrm{SD}=1,254)$, ali, istovremeno, i viši nivo tradicionalnih vrednosti (AS $=5,820, \mathrm{SD}=1,122) \mathrm{u}$ odnosu na muškarce $(\mathrm{AS}=5,570$, $\mathrm{SD}=1,314)$.

Tabela 6 Rezultati t testa za dva nezavisna uzorka

\begin{tabular}{|c|c|c|c|c|c|c|}
\hline & \multicolumn{2}{|c|}{ Muškarci } & \multicolumn{2}{|c|}{ Žene } & \multirow{2}{*}{ vrednost } & \multirow{2}{*}{ Sig. } \\
\hline & AS & SD & AS & SD & & \\
\hline $\begin{array}{l}\text { Kosmo- } \\
\text { politizam }\end{array}$ & 4,888 & 1,254 & 5,296 & 1,201 & $-3,162$ & 0,002 \\
\hline Tradicija & 5,570 & 1,314 & 5,820 & 1,122 & $-1,953$ & 0,050 \\
\hline
\end{tabular}

Izvor: Autor

\section{ZAKLJUČAK}

Cilj ovog istraživanja bio je analiza faktora koji utiču na određene aspekte ponašanja potrošača $u$ vezi sa restoranima brze hrane, a to su procene proizvoda i namere u ponašanju. Faktori čiji je uticaj analiziran su kosmopolitizam i tradicija potrošača.

Rezultati istraživanja ukazuju na izraženi pozitivan i statistički značajan uticaj faktora kosmopolitizam na procene proizvoda i usluga stranih restorana brze hrane. Analiza uticaja tradicije na procene proizvoda i usluga pokazala je da tradicija ima pozitivan, statistički značajan uticaj na procene domaćih restorana brze hrane.

Pored navedenih rezultata, analizom nije dokazano da kosmopolitizam ima negativan uticaj na procene proizvoda i usluga domaćih restorana, kao ni da tradicija ima negativan uticaj na procene stranih restorana brze hrane. Ovakvi rezultati ukazuju da osobe koje su kosmopolitski orijentisane ne moraju biti negativno nastrojene prema domaćim proizvodima i uslugama. Takođe, posedovanje tradicionalnih vrednosti ne mora podrazumevati negativne stavove prema stranim proizvodima i uslugama. Rezultati sprovedenog istraživanja pokazuju da tradicionalni potrošači mogu biti potencijalni segment ne samo za domaće, nego i za međunarodne restorane brze hrane. Takođe, kosmopolitski potrošači mogu biti potencijalni segment ne samo za međunarodne nego i za domaće restorane brze hrane.

Značaj i doprinos ovog istraživanja se ogleda $u$ popunjavanju jaza, usled nedostatka radova o ovom istraživačkom problemu u Republici Srbiji, generalno, u uslužnom sektoru, a pogotovu, u sektoru restorana brze hrane. Rezultati sprovedenog istraživanja mogu biti od značaja za poslovnu praksu i upravljanje restoranima brze hrane, jer pružaju analizu stavova potrošača $u$ pogledu procena proizvoda i usluga koji su prisutni u restoranima i njihovih namera u pogledu budućeg ponašanja, što je od ključnog značaja za uspeh poslovnih aktivnosti međunarodnih lanaca brze hrane. Takođe, ovakva analiza je od značaja, jer može pomoći u formulisanju strategije promocije domaćih restorana brze hrane, stavljanjem posebnog akcenta na tradicionalne aspekte, čime će se uticati pozitivno na stavove potrošača koji cene ove vrednosti. Obrnuto, ukoliko menadžment domaćih restorana želi da privuče potrošače koje odlikuje kosmopolitizam, ponuda i promocija ovih restorana se treba prilagoditi aktuelnim svetskim trendovima i proizvodima koji se mogu pronaći u stranim restoranima brze hrane.

S druge strane, međunarodni lanci brze hrane bi mogli imati koristi od navedenih rezultata istraživanja, u pogledu formulisanja i kreiranja 
sopstvene ponude i promocije. Iako je jasno da su za međunarodne restorane od velike važnosti potrošači koji su kosmopolitski orijentisani, uvođenjem u svoju ponudu proizvoda prilagođenih ukusima i željama lokalnih potrošača, bi moglo da privuče i tradicionalne potrošače.

Takođe, rezultati istraživanja ukazuju da postoje značajne razlike između stavova različitih grupa potrošača, što može biti od značaja za definisanje ciljnih segmenata prilikom formulisanja strategija promocije i uslužne ponude restorana brze hrane.

Sprovedeno istraživanje ima određena ograničenja. Imajući u vidu činjenicu da je istraživanje sprovedeno na teritoriji Kragujevca i okolnih gradova, navedeni rezultati iskazuju stavove potrošača iz navedenog regiona, što može biti problem u smislu generalizacije rezultata $\mathrm{i}$ njihove primene $\mathrm{u}$ drugim regionima i državama. Radi postizanja većeg stepena generalizacije, buduća istraživanja bi, svakako, trebalo da obuhvate veći broj tržišta i potrošača, što bi obezbedilo i mogućnosti za širu komparativnu analizu. Takođe, kao ograničenje istraživanja se javlja i činjenica da njime nisu obuhvaćene druge varijable koje mogu uticati na stavove potrošača o stranim i domaćim restoranima brze hrane, kao što su materijalizam, etnocentrizam ili animozitet potrošača i druge varijable, koje se koriste u sličnim istraživanjima. Pravci budućih istraživanja mogu obuhvatiti analizu direktnih ili medijatorskih uticaja dodatnih faktora, kao što su etnocentrizam, uključenost $u$ proces donošenja odluke o kupovini ili materijalizam, na procene i namere potrošača u pogledu korišćenja usluga domaćih i stranih restorana brze hrane.

\section{REFERENCE}

Ajzen, I. (1991). The theory of planned behavior. Organizational Behavior And Human Decision Processes, 50(2), 179-211. doi: org/10.1016/0749-5978(91)90020-T

Ajzen, I., \& Fishbein, M. (1980). Understanding attitudes and predicting social behavior. Englewood Cliffs, NJ: PrenticeHall.
Alden, D. L., Steenkamp, J. E., \& Batra, R. (1999). Brand positioning through advertising in Asia, North America, and Europe: The role of global consumer culture. Journal of Marketing, 63(1). 75-87.

Cleveland, M., \& Laroche, M. (2007). Acculturation to the global consumer culture: Scale development and research paradigm. Journal of Business Research, 60(3), 249-259. doi: 10.1016/j.jbusres.2006.11.006

Cleveland, M., Laroche, M., \& Hallab, R. (2013). Globalization, culture, religion, and values: Comparing consumption patterns of Lebanese Muslims and Christians. Journal Of Business Research, 66(8), 958-967. doi: 10.1016/j.jbusres.2011.12.018

Cleveland, M., Laroche, M., \& Papadopoulos, N. (2009). Cosmopolitanism, consumer ethnocentrism, and materialism: An eight-country study of antecedents and outcomes. Journal of International Marketing, 17(1), 116-146. doi: org/10.1509/jimk.17.1.116

Cleveland, M., Papadopoulos, N., \& Laroche, M. (2011). Identity, demographics, and consumer behaviors. International Marketing Review, 28(3), 244-266. doi: org/10.1108/02651331111132848

Costa, C., Carneiro, J., \& Goldszmidt, R. (2016). A contingent approach to country-of-origin effects on foreign products evaluation: Interaction of facets of country image with product classes. International Business Review, 25, 10661075. doi: 10.1016/j.ibusrev.2016.01.003

Field, A. (2000). Discovering Statistics Using SPSS for Windows. Thousand Oaks, CA: Sage Publication.

Fishbein, M., \& Ajzen, I. (1975). Belief, Attitude, Intention and Behavior: an Introduction to Theory and Research. Boston, Massachusetts: Addison-Wesley.

Grünhagen, M., Dant, R. P., \& Zhu, M. (2012). Emerging consumer perspectives on American franchise offerings: Variety seeking behavior in China. Journal of Small Business Management, 50(4), 596-620. doi. org/10.1111/ j.1540-627Х.2012.00368.x

Hong, S.-T., \& Wyer, R. S. Jr. (1989). Effects of Countryof-Origin and Product-Attribute Information on ProductEvaluation: An Information Processing Perspective. Journal of Consumer Research, 16(2), 175-87. 
Jin, Z., Lynch, R., Attia, S., Chansarkar, B., Gülsoy, T., Lapoule, P., \& Ungerer, M. (2015). The relationship between consumer ethnocentrism, cosmopolitanism and product country image among younger generation consumers: The moderating role of country development status. International Business Review, 24(3), 380-393. doi: 10.1016/j.ibusrev.2014.08.010

Josiassen, A., \& Harzing, A.-W. (2008). Descending from the ivory tower: Reflections on the relevance and future of country of-origin research. European Management Review, 5(4), 264-270. doi: 10.1057/emr.2008.19

Kim, E., Ham, S., Yang, I., \& Choi, J. (2013). The roles of attitude, subjective norm, and perceived behavioral control in the formation of consumers' behavioral intentions to read menu labels in the restaurant industry. International Journal of Hospitality Management, 35(0), 203213. doi: 10.1016/j. ijhm.2013.06.008

Laroche, M., Papadopoulos, N., Heslop, L., \& Mourali, M. (2005). The influence of country image structure on consumer evaluations of foreign products. International Marketing Review, 22(1), 96-115. doi: org/10.1108/02651330510581190

Magnusson, P., Westjohn, S., \& Zdravkovic, S. (2011). What? I thought Samsung was Japanese: Accurate or not, perceived country of origin matters. International Marketing Review, 28(5), 454-472. doi: org/10.1108/02651331111167589

Manrai, L., Lascu, D.-N., \& Manrai, A. (1998). Interactive effects of country of origin and product category on product evaluations. International Business Review, 7(6), 591-615.

McCall, M., \& Lynn, A., (2008). The effects of restaurant menu item descriptions on perceptions of quality, price and purchase intentions. Journal of Foodservice Business Research. 11(4), 439-445. doi: org/10.1080/15378020802519850

Nijssen, E. J., \& Douglas, S. P. (2008). Consumer worldmindedness, social-mindedness, and store image. Journal Of International Marketing, 16(3), 84-107. doi: 10.1509/jimk.16.3.84

Nunnally, J. C. (1978). Introduction to Psychological Measurement. New York, NY: McGraw-Hill.

Oliver, R. L. (1996). Satisfaction: A Behavioral Perspective on the Consumer. New York, NY: McGraw-Hill.
Peterson, R. A., \& Jolibert, A. J. P. (1995). A meta-analysis of country-of-origin effects. Journal of International Business Studies, 26(4), 883-900. doi.org/10.1057/palgrave.jib

Pharr, J. M. (2005). Synthesizing country-of-origin research from the last decade: Is the concept still salient in an era of global brands? Journal of Marketing Theory and Practice, 13(4), 34-45. doi.org/10.1080/10696679.2005.11658557

Riefler, P., \& Diamantopoulos, A. (2009). Consumer cosmopolitanism: Review and replication of the CYMYC scale. Journal of Business Research, 62(4), 407-41. doi. org/10.1016/j.jbusres.2008.01.041

Riefler, P., Diamantopoulos, A., \& Siguaw, J. A. (2012). Cosmopolitan consumers as target group for segmentation. Journal of International Business Studies, 43(3), 285-305. doi.org/10.1057/jibs.2011.51

Schwartz, S. H. (1992). Universals in the content and structure of values: Theory and empirical tests in 20 countries. In M. Zanna (Ed.). Advances in experimental social psychology (pp. 1-65), 25, New York, NY: Academic Press. doi.org/10.1016/S0065-2601(08)60281-6

Schwartz, S. H. (1994). Are there universal aspects in the content and structure of values? Journal of Social Issues, 50(4), 19-45. doi: 10.1111/j.1540-4560.1994.tb01196.x

Schwartz, S., Cieciuch, J., Vecchione, M., Davidov, E., Fischer, R., Beierlein, C., Ramos, A., Verkasalo, M. Lonnqvist, J., Demirutku, K., Dirilen-Gumus, O., \& Konty, M. (2012). Refining the theory of basic individual values. Journal Of Personality And Social Psychology, 103(4), 663-688. doi: 10.1037/a0029393

Sharma, P. (2011). Country of origin effects in developed and emerging markets: Exploring the contrasting roles of materialism and value consciousness. Journal of International Business Studies, 42(2), 285-306. doi:10.1057/ jibs. 2010.16

Skrbis, Z., Kendall, G., \& Woodward, I. (2004). Locating cosmopolitanism: Between humanist ideal and grounded social category. Theory, Culture \& Society, 21(6), 115-136. doi: 10.1177/0263276404047418

Steenkamp, J.-B. E. M., \& de Jong, M. G. (2010). A Global Investigation into the constellation of consumer attitudes toward global and local products. Journal Of Marketing, 74(6), 18-40. doi: org/10.1509/jmkg.74.6.18 
Steenkamp, J.-B. E. M., Hofstede, F. T., \& Wedel, M. (1999). A cross-national investigation intothe individual and national cultural antecedents of consumer innovativeness. Journal of Marketing, 63(2), 55-69. doi: 10.2307/1251945

Tajfel, H. (1978). Social categorization, social identity and social comparison. In H. Tajfel, (Ed.). Differentiation Between Social Groups: Studies in the Social Psychology of Intergroup Relations (pp. 61-76). London, UK: Academic Press.

Tajfel, H., \& Turner, J. C. (1986). The social identity theory of intergroup behavior. Psychology of Intergroup Relations, 5, $7-24$.

Verlegh, P. W. J. (2007). Home country bias in product evaluation: The complementary roles of economic and socio-psychological motives. Journal of International Business Studies, 38(3), 361-73. doi: org/10.1057/palgrave. jibs. 8400269

Verlegh, P. W. J., \& Steenkamp, J.-B. E. M. (1999). A review and meta-analysis of country-of-origin research. Journal of Economic Psychology, 20(5), 521-546.
Wang, C., \& Mattila, A. S. (2015). The impact of servicescape cues on consumer prepurchase authenticity assessment and patronage intentions to ethnic restaurants. Journal Of Hospitality \& Tourism Research, 39(3), 346-372. doi: $10.1177 / 1096348013491600$

Westjohn, S. A., Arnold, M. J., Magnusson, P., \& Reynolds, K. (2016). The influence of regulatory focus on global consumption orientation and preference for global versus local consumer culture positioning. Journal of International Marketing, 24(2), 22-39. doi: 10.1509/ jim. 15.0006

Zeugner-Roth, K. P., Žabkar, V., \& Diamantopoulos, A. (2015). Consumer ethnocentrism, national identity, and consumer cosmopolitanism as drivers of consumer behavior: A social identity theory perspective. Journal Of International Marketing, 23(2), 25-54. doi: 10.1509/ jim.14.0038

http://www.ibisworld.com/industry/global/global-fastfood-restaurants.html

Primljeno 21. juna 2017, nakon dve revizije, prihvaćeno za publikovanje 23. avgusta 2017. Elektronska verzija objavljena 25. avgusta 2017.

Srđan Šapić je vanredni profesor Ekonomskog fakulteta Univerziteta u Kragujevcu, na nastavnim predmetima Međunarodni marketing, Međunarodno poslovanje i Menadžment i marketing usluga. Doktorirao je na Ekonomskom fakultetu Univerziteta u Kragujevcu. Oblasti njegovog naučnog interesovanja su međunarodno marketing okruženje, marketing usluga, interkulturalni marketing, oblici internacionalizacije preduzeća. 


\title{
THE EFFECTS OF COSMOPOLITANISM AND TRADITION ON THE EVALUATION AND INTENTIONS OF THE USERS OF FAST FOOD RESTAURANTS
}

\author{
Srdjan Sapic \\ Faculty of Economics, University of Kragujevac, Kragujevac, The Republic of Serbia
}

In terms of modern life, consumers have an increasing number of options when it comes to choosing a restaurant when they do not wish to eat at their homes. Fast food restaurants represent one of those options. In addition to domestic fast food restaurants, the development of global restaurant chains is also noticeable. The purpose of this paper is to identify the factors that affect the evaluations of products and services and the intentions of users in terms of using the services of fast food restaurants. In relation to that, it is important to analyze the factor of cosmopolitanism and tradition. Cosmopolitanism, as the willingness of people to cooperate with other cultures and tradition, and tradition, as a reflection of respect for the customs and ideas that are imposed on individuals by their culture or religion, affect consumers' intentions and their willingness to use the services of foreign fast food restaurants. In accordance with that, the purpose of this research study is to determine if and how cosmopolitanism and tradition affect the evaluations of products and services and consumers' intention concerning foreign restaurant chains and domestic fast food restaurants of both the local and the family types. The results of the conducted empirical research show that cosmopolitanism positively affects the evaluations of the products and services of foreign restaurants and that tradition positively affects the evaluations of the products and services of domestic fast food restaurants.

Keywords: cosmopolitanism, tradition, evaluations of products and services, consumer behavioral intentions, fast food restaurants

JEL Classification: M31, L83 